\title{
Clinical application of ultrasound in dermatological cases
}

\author{
Niken Wulandari ${ }^{1}$, Ryo Tanaka ${ }^{1}$, Hiroaki Hayashi ${ }^{1}$, Jiro Hata ${ }^{2}$, Wataru Fujimoto ${ }^{1}$
}

\begin{abstract}
Abstrak
Ultrasonografi telah dikenal sebagai suatu modalitas penting dalam dunia kedokteran dan telah memasuki bidang dermatologi klinis. Karakteristiknya yang non-invasif membuatnya mudah digunakan dan sepenuhnya aman. Ultrasonografi menghasilkan informasi diagnostik yang penting pada evaluasi tumor kulit. Selain itu juga dapat menerangkan lesi-lesi subkutan dan hubungannya dengan jaringan sekitarnya. Teknik ultrasonografi lainnya dengan menggunakan Doppler berwarna berguna untuk menilai vaskularisasi pada lesi kulit. Dalam tulisan ini, kami ingin menggambarkan aplikasi ultrasonografi pada sejumlah kasus terpilih dari institusi kami. (Med J Indones 2007; 16:113-6)
\end{abstract}

\begin{abstract}
Ultrasonography has been recognized as an important diagnostic modality in medicine and has entered the area of clinical dermatology. Its non-invasive characteristics have made it easily use and completely safe. It provides important diagnostic information in evaluating skin tumors. It also outlines the subcutaneous lesions and their relation to its adjacent tissue. Another ultrasound technique is color Doppler which is useful to assess vascularization of skin lesion. In this article, we would like to report ultrasound imaging in some selected cases from our institution. (Med J Indones 2007; 16:113-6)
\end{abstract}

Keywords: Ultrasound, skin tumor, arteriovenous malformation, pseudoaneurysm

Ultrasound imaging has been widely used in clinical medicine. This non-invasive modality is safe without major harmful effects to the tissue that made it applicable in many fields amongst them are/especially internal medicine and obstetric gynecology. An ultrasound machine works by emitting high frequency waves from the transducer and receive the backscatter from the target tissue. Different characteristics and furthermore processed by the system into different gradation of brightness on the ultrasound image. The ability of ultrasound to distinguish two close objects within the tissue is known as resolution, which includes spatial and temporal resolutions. ${ }^{2,3}$

With the invention of higher frequency transducers, ultrasound has entered the area of clinical dermatology. ${ }^{1}$ In clinical dermatology, the lesions are mostly found in the surface of the body, either in epidermis, dermis or subcutaneous tissue. With increasing frequency, the penetration of ultrasound waves will decrease. For example, ultrasound unit using $20 \mathrm{MHz}$ penetrates approximately only to $8 \mathrm{~mm}$ of human body.

\footnotetext{
${ }^{1}$ Department of Dermatology, Kawasaki Medical School, Kurashiki City, Okayama, Japan

${ }^{2}$ Division of Endoscopy and Ultrasound, Department of Pathology and Laboratory Medicine, Kawasaki Medical School, Japan
}

At present, there are two basic types of transducers used for dermatologic application, one for diagnosis of regional lymph nodes and soft tissue tumors with intermediate frequency range from 7.5 to $15 \mathrm{MHz}$ and another with high-frequency transducer (20 to 50 $\mathrm{MHz}$ ) for evaluating cutaneous structure function. ${ }^{1,4}$

The frequency of ultrasound system used in the present cases ranged from $7.5 \mathrm{MHz}$ to $12 \mathrm{MHz}$. The choice of the frequency depended on the lesion depth, size and site. The $12 \mathrm{MHz}$ linear probe was used to assess superficial and subcutaneous lesion such as tumors, assessing their relationship to the adjacent tissue including nerves and vessels to provide crucial preoperative information. Meanwhile, the $7.5 \mathrm{MHz}$ linear probe was used to assess the lesions which were larger and/or located in deeper area. Color Doppler was performed to analyze vasculature of the skin lesions. The ultrasound equipment employed in this report was SSA-770A (Toshiba, Japan).

\section{CASES REPORT}

\section{Case 1: Basal cell carcinoma}

A 76-year-old man came with 10 years history of a skin lesion on the right occipital region that became 
progressively ulcerated (Fig.1, upper). Physical examination revealed a 40 x $40 \mathrm{~mm}$ dome-shaped ulcerated mass with inferior induration measured $50 \mathrm{x}$ $50 \mathrm{~mm}$ that seemed to be fixed to the bone. Clinical findings suggested a malignant skin tumor with suspicion of a bone invasion. Ultrasound examination was performed to evaluate tumor dimension, its depth of penetration and vascularity. The echogram detected an echogenic mass surrounded by hypoechoic border clearly indicating that there was no attachment between the tumor and periosteum (Fig.1, lower). Doppler examination demonstrated marked vascularization within the tumor indicating a malignancy. Pathological finding confirmed a basal cell carcinoma. Further assessment by computed tomography (CT)-scan and magnetic resonance imaging (MRI) has also confirmed no bone invasion. Treatment was done by radical excision and the tissue defect was reconstructed with a transposition flap.
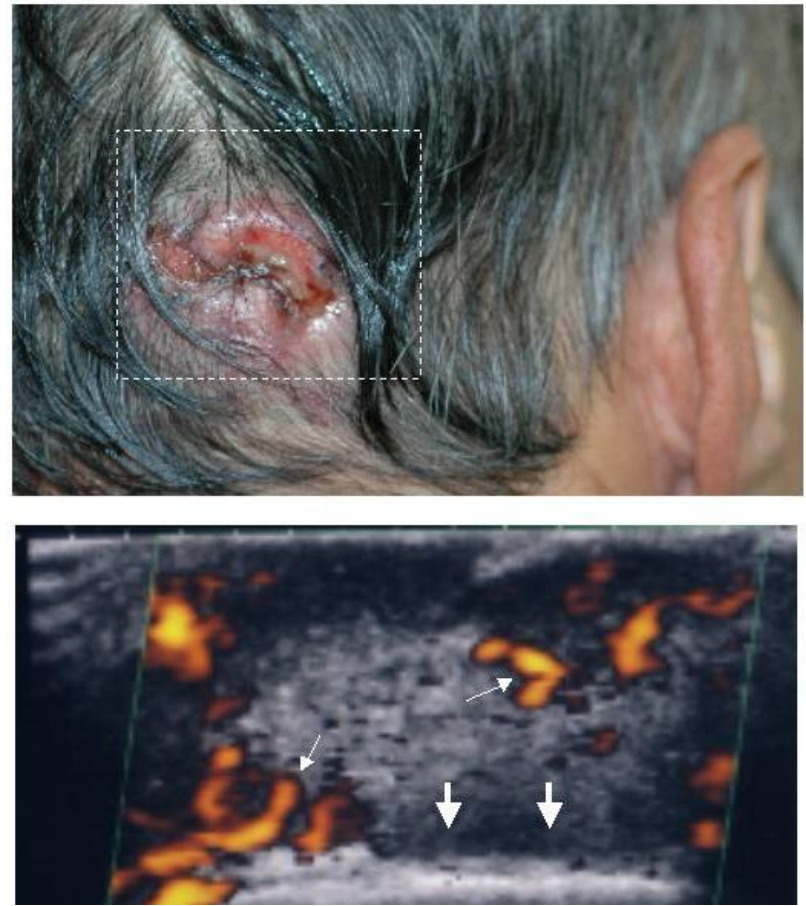

Figure 1. Image from case 1: Basal cell carcinoma. An ulcerated skin lesion was found in occipital region (upper). Its ultrasound image reveals a mass with marked neo-vascularization (lower, thin arrows) surrounded by a clear border (lower, bold arrows).

\section{Case 2: Arteriovenous malformation}

A 27-year-old woman apparently had a 10 years history of localized hyperemic subcutaneous node with diameter $2.5 \mathrm{~cm}$ in the left lower anterior tibial region. On physical examination the beat was slightly palpated and bruit sound was clearly heard within the lesion. Ultrasound examination was performed for diagnostic purpose. The echogram showed an area with multiple anechoic canal appearances (Fig. 2, upper). Color Doppler examination revealed a mixed flow pattern of vasculature indicating various directions of blood flow suggesting abnormal structure of the vessels (Fig. 2, lower). These findings are typical for an arteriovenous malformation (AVM). The transducer followed the abnormal vessel flow and found that AV shunts partially connected anterior tibial artery and great saphenous vein. Further MRI examination has confirmed the diagnosis. Treatment was done by resection of the nidus.
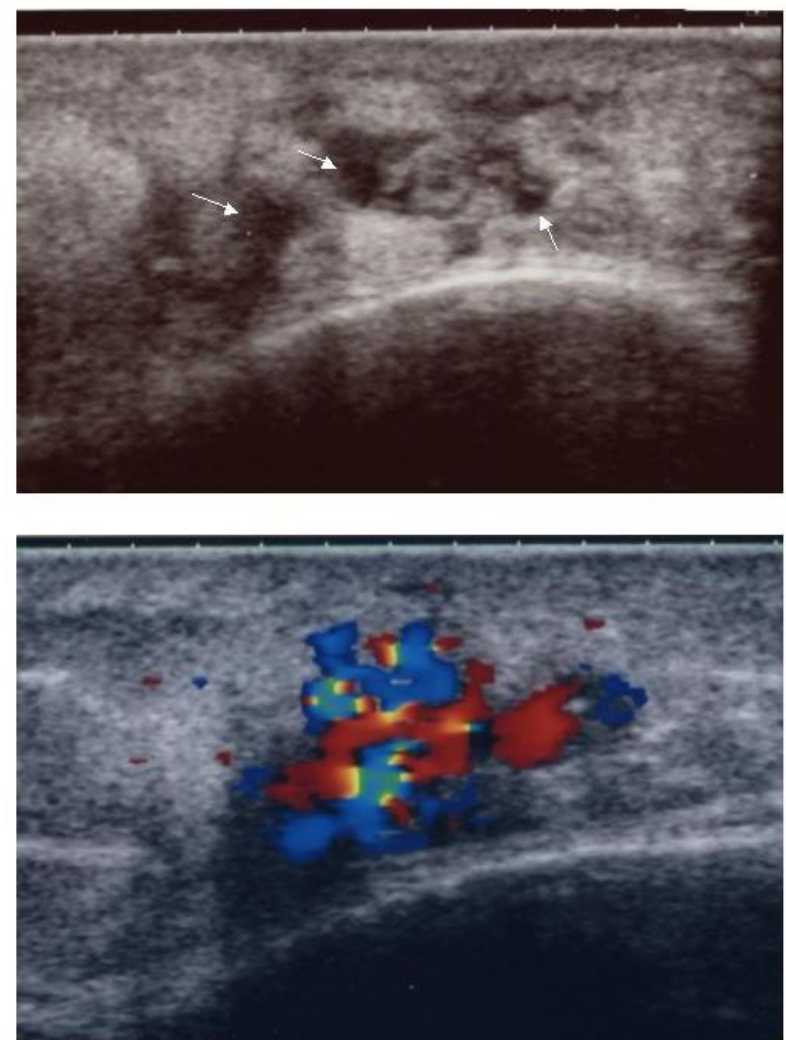

Figure 2. Images from case 2: Subcutaneous arteriovenous malformation. Area with numerous enlarged vessels with anechoic canal appearances is shown (upper, arrow) and color Doppler demonstrates a mixed flow pattern of vasculature with various directions of flow (lower).

\section{Case 3: Femoral pseudoaneurysm}

A 70-year-old man came to our department with a 3 months history of a gradually enlarging mass on the right anterior femoral region accompanied by fever 
up to $40^{\circ} \mathrm{C}$ for few days. There was no history of trauma or catheterization procedure through femoral access. Physical examination revealed a tender nonpulsating subcutaneous mass with diameter about $10 \mathrm{~cm}$. The surface of the mass was warm, slightly erythematous and pain on pressure. Blood examination revealed leukocytosis, high blood sedimentation rate and high level of C-reactive protein (CRP). Ultrasound examination was performed to assess the morphology of the subcutaneous mass. Color Doppler examination revealed blood flows that come in and out of a large hypoechoic cavity (Fig. 3, upper). Angiography confirmed an area filled by the contrast attached to the right femoral artery (Fig. 3, lower). These evidences suggested an infected femoral pseudoaneurysm. A surgical procedure was performed to remove the mass.
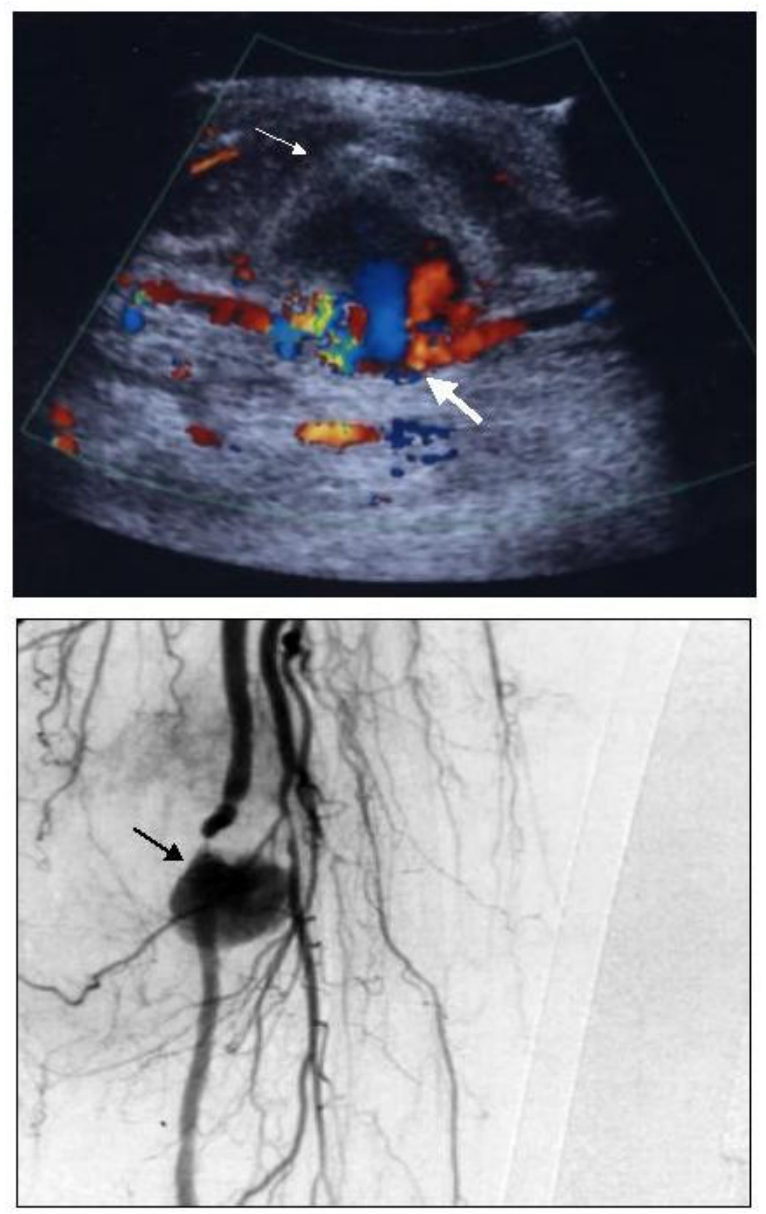

Figure 3. Images from case 3: Arterial pseudoaneurysm. Ultrasound image reveals a hypoechoic subcutaneous mass bulging toward the skin (upper, thin arrows) with to-and-fro flow pattern within the aneurysm neck from femoral artery suggesting a pseoudoaneurysm (upper, bold arrows), which was confirmed by angiographic examination (lower, arrow).

\section{DISCUSSION}

In the first case, patient was diagnosed with a basal cell carcinoma lesion on suspicion of having a bone invasion. This possibility should be investigated with a complete physical examination, skin imaging and bone scan. ${ }^{5}$ Ultrasound provided preoperative information about tumor dimension, its depth penetration and vascularization, which is crucial regarding therapeutic strategies. Another way to confirm an attachment of a skin tumor to its surrounding tissue is using a sliding method guided by ultrasound. By moving the tumor, it can be seen in the ultrasound monitor whether there is a sliding of the tumor relative to its surrounding tissues. Color Doppler sonography can also be used to differentiate benign and malignant tumors. The presence of vascularization indicates the malignancy of the tumor. $^{6}$

The second case was a rare vascular malformation with direct communications (AV shunting) creating an AV nidus. ${ }^{7}$ The diagnosis of clinically suspected AVM is confirmed by ultrasound. Gray-scale ultrasonography coupled with color Doppler sonography confirms the presence of arteriovenous fistulae and provides information regarding lesion morphology and vascular components. Ultrasound image visualized AV fistulae as a large anechoic channel surrounded by thickening subcutaneous tissue. Color Doppler revealed numerous enlarged vessels coursing through the subcutaneous tissue. Other advantages of using ultrasound in such case are that it can distinguish between soft tissue hemangioma from vascular malformation and differentiate a type of malformation from another. These distinctions are critical for subsequent management and assessing prognosis. ${ }^{8}$

The third case was an infected femoral pseudoaneurysm, caused by disruption of one or more arterial wall layers. ${ }^{9}$ Previously, the differential diagnosis of the mass was an infected subcutaneous tumor in which a centesis drainage for bacterial culture and biopsy for tumor diagnostic should be considered. Assessment by ultrasound showed to-and-fro blood flow pattern from the mass suggesting a vascular aneurysm, preventing invasive procedure (drainage and biopsy) that would lead to a massive bleeding.

Conclusions ultrasound imaging plays an important role in providing diagnostic information for skin tumor and vascular abnormalities. Gray-scale ultrasonography combined with color Doppler flow technique has the advantage of providing a rapid, relatively 
inexpensive, and non-invasive assessment of lesion morphology and vascularity.

\section{REFERENCES}

1. Cammarota T, Pinto F, Magliaro A, Sarno A. Current uses of diagnostic high- frequency US in dermatology. Eur J Radiol. 1998; 27 Suppl 2:S215-23.

2. Ralland D, Harland CC. Ultrasound in dermatology-basic principles and applications. Exper Dermatol. 2003; 28: 632-8.

3. Whittingham TA. New and future developments in ultrasonic imaging. Br J Radiol. 1997; 70 spec.: S119-32.

4. Schmid-Wendtner MH, Burgdorf W. Ultrasound scanning in dermatology. Arch Dermatol. 2005; 141: 217-24.
5. Aygit C, Top H, Bilgi S, Ozbey B. Invading basal cell carcinoma of the bone: diagnosis and treatment approaches. J Oral Maxillofac Surg. 2006; 64: 1143-8.

6. Karaman GC, Karaman ZC, Sendur N, Akdili A, Basak S, Savk EB. Power Doppler ultrasonography for the evaluation of skin tumors other than malignant melanoma. Eur Radiol. 2001; 11: 1111-6.

7. Enjolras O. Vascular malformation. In: Bolognia JL, Jorizzo JL, Rapini RP. Dermatology. Mosby Elsevier Ltd; 2003. p. 1615-29.

8. Paltiel HJ, Burrows PE, Kozakewich HPW, Zurakowski D, Mulliken JB. Soft-tissue vascular anomalies: utility of US for diagnosis. Radiology 2000; 214:747-54.

9. Stone PA, AbuRahma AF, Flaherty SK, Bates MC. Femoral pseudoaneurysms. Vasc Endovasc Surg. 2006; 40:109-17. 